\title{
Estimating regional model parameters using spatial land cover information - implications for predictions in ungauged basins
}

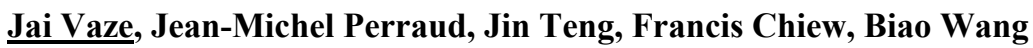 \\ CSIRO Land and Water, GPO Box 1666, Canberra, ACT 2601, Australia \\ Email:Jai.Vaze@csiro.au
}

\begin{abstract}
There have been numerous regionalization studies on runoff prediction in ungauged catchments. Most studies calibrate the rainfall-runoff (RR) models against gauged streamflow data and use regionalisation methods to specify parameter values to model runoff in the ungauged catchments. This study evaluates the relative benefits of different calibration (local and regional) and regionalisation methods (nearest neighbour and regional forest and non-forest parameters). The modelling experiments are carried out using two RR models (Sacramento and SIMHYD) and daily climate and streamflow data for 10 unregulated gauged catchments from southeast Australia.

Three sets of model calibrations are carried out. In the first set, the rainfall-runoff models are calibrated to individual catchments. In the second set, spatial land cover information is used to calibrate two sets of rainfall-runoff model parameters (one set for forest and another for non-forest, a total of two calibrated parameter sets for all 10 catchments). In the third set, a cross-verification analysis is carried out where one catchment is dropped out in turn and the models are calibrated to the remaining nine catchments together using forest and non-forest land cover labels for individual grid cells within each catchment (one set for forest and another for non-forest, a total of two calibrated parameter sets for all nine catchments). The calibrated models ability to predict runoff in 'ungauged' catchments is then assessed by: (i) using parameter values from the geographically closest gauged catchment (nearest neighbour regionalisation); (ii) using forest and non-forest parameter sets calibrated to the remaining nine catchments (forest and non-forest regionalisation).
\end{abstract}

The calibration results show that the median of Nash-Sutcliffe efficiency (NSE) for the 10 catchments for individual catchment calibration is slightly higher than that for the regional forest and non-forest calibration. This is to be expected as we are calibrating only two sets of parameter values in the latter case instead of 10 sets. But the regionalisation results show that incorporating spatial land cover information in the gridded calibration of RR model improves runoff prediction in ungauged catchments with the median of regionalisation NSE for the forest and non-forest regionalisation significantly higher than that for the nearest neighbour method.

The results and conclusions here are based on analysis undertaken using only 10 catchments and all these catchments are in close proximity with similar climate and physical characteristics. The results may be different when using catchments spread across a larger region. But the results here suggest that this approach can provide better estimates of runoff within a river basin and it has the potential to be used to estimate the impacts of land cover change. We are currently exploring the applicability and suitability of the approach over a larger region using data from 100 catchments in southeast Australia.

Keywords: Rainfall-runoff models, Regional calibration, Regionalisation, PUB 


\section{INTRODUCTION}

Reliable estimates of runoff are critical for undertaking water resources assessments to support river basin planning and management. In most of the large river basins, there are usually a small number of unregulated well-gauged catchments and most of the remaining catchments are usually poorly gauged or ungauged. For example, the Murray-Darling Basin (MDB) in Australia covers about 1 million $\mathrm{km}^{2}$ and the unregulated gauged catchments only cover about $9 \%$ of the MDB. In the last few decades, considerable research has been directed towards developing and implementing methods for predicting runoff in ungauged catchments. The International Association of Hydrological Sciences (IAHS) launched an initiative, the IAHS Decade on PUB (2003-2012) (Predictions in Ungauged Basins Initiative), focusing on "formulating and implementing appropriate science programmes to engage and energize the scientific community, in a coordinated manner, towards achieving major advances in the capacity to make reliable predictions in ungauged basins" (Sivapalan, et al., 2003). Regionalisation is typically used for water quantity studies in PUB, and is referred as the process of transferring optimised parameter values from a gauged catchment to the target ungauged catchment (Bloschl and Sivapalan, 1995).

Three regionalisation approaches have been widely used to choose the donor gauged catchment whose optimised parameter values are used to model runoff for the target ungauged catchment: regression; spatial proximity; and physical similarity. The regression approach establishes a relationship between parameter values calibrated on gauged catchments and catchment descriptors or attributes (climatic and physical), and then the parameter values for the ungauged catchments are estimated from its attributes and the established relationship. The spatial proximity approach uses the calibrated parameter values from the geographically closest gauged catchment. The underlying supposition here is that neighbouring catchments should behave similarly owing to similar physical and climatic characteristics. The physical similarity approach transfers the entire set of parameter values from a physically similar catchment whose attributes (climatic and physical) are similar to those of the target ungauged catchment.

The regression approach has been widely used in regionalisation studies (Young, 2006) but it has been strongly criticised by a number of researchers in the recent past (Bardossy, 2007; Oudin, et al., 2008). The main argument against the regression approach is that the cross-correlation between parameters are seldom taken into account and because model calibrations can produce vastly different sets of parameter values that give similar model performance i.e. the equifinality problem (Beven and Freer, 2001). The spatial proximity and physical similarity approaches have been more popular and used in several recent regionalisation studies (Bardossy, 2007; Merz and Bloschl, 2004; Oudin, et al., 2008b; Parajka, et al., 2005; Vaze and Teng, 2011). Merz and Bloshl (2004) and Parajka et al. (2005) compare the three regionalisation approaches in over 300 Austrian catchments using an 11-parameter HBV model and show that the spatial proximity approach performs best followed by the physical similarity approach with the regression approach performing worst. Oudin et al. (2008) draw the same conclusion using two rainfall-runoff models, GR4J and TOPMO, in 913 French catchments. In their study, they argue that as the spatial proximity approach does not systematically outperform the physical similarity approach, combining the two to select a donor catchment may improve the modelling results.

Although the physical similarity approach transfers the calibrated parameter values from a gauged to an ungauged catchment based on similarity in physical and climatic conditions, it does not take into account the catchment physical properties such as land cover in the model calibration itself. The runoff from a catchment is mainly controlled by climatic conditions, but it is also strongly influenced by land use/land cover because of anthropogenic activities (Nandakumar and Mein, 1997; Vertessy, 1999; Vaze et al., 2004; Tuteja at al, 2007; Elfert and Bormann, 2010). Zhang and Chiew (2008) used remotely sensed vegetation data in conceptual rainfall-runoff modelling and showed that this can improve runoff estimates in ungauged catchments. They undertook a lumped application of the conceptual model but modified the conceptual model structure to incorporate the catchment averaged impact of vegetation cover by changing the evapotranspiration algorithms.

This paper investigates the use of land cover data at fine resolution in a gridded application of two conceptual rainfall-runoff models (Sacramento and SIMHYD) using data from 10 unregulated catchments in Victoria, Australia. The main focus of this paper is to incorporate the spatial variability of land cover across a catchment in the model calibration process to investigate whether the parameters derived using this approach can capture the varied catchment response under different land covers (forest and non-forest) and whether this provides better estimates of runoff when we transfer the calibrated parameters to ungauged catchments. 


\section{STUDY AREA AND DATA}

The ten study catchments are located in the winter -rainfall dominated region of Victoria, Australia and the catchment areas vary between $160 \mathrm{~km}^{2}$ and $1240 \mathrm{~km}^{2}$ (Figure 1). The catchments are largely unregulated with no major storages or irrigation schemes, as determined from knowledge of the drainage systems, advice from state water agencies and interpretation of spatial images. The forest cover in these catchments varies from $\sim 5 \%$ to $100 \%$.

The climate data are derived from the SILO Data Drill (http://www.longpaddock.qld.gov.au/silo; Jeffrey et al. 2001) which provides surfaces of daily climate data for $0.05^{\circ}$ grids $(\sim$ $5 \mathrm{~km} \times 5 \mathrm{~km}$ ) across Australia, interpolated from point measurements made by the Australian Bureau of Meteorology.

The streamflow data are collated as part of the Catchment Water Yield Estimation Tool (CWYET) project and have been checked for errors to be usable in large scale hydrological modelling (Vaze et al., 2011a). The main checks for errors include plotting time series and scatter plots of monthly rainfall and streamflow (and runoff coefficient) to identify inconsistency in the data and checking for recording errors (spikes in data, same data value for a long period, etc.).

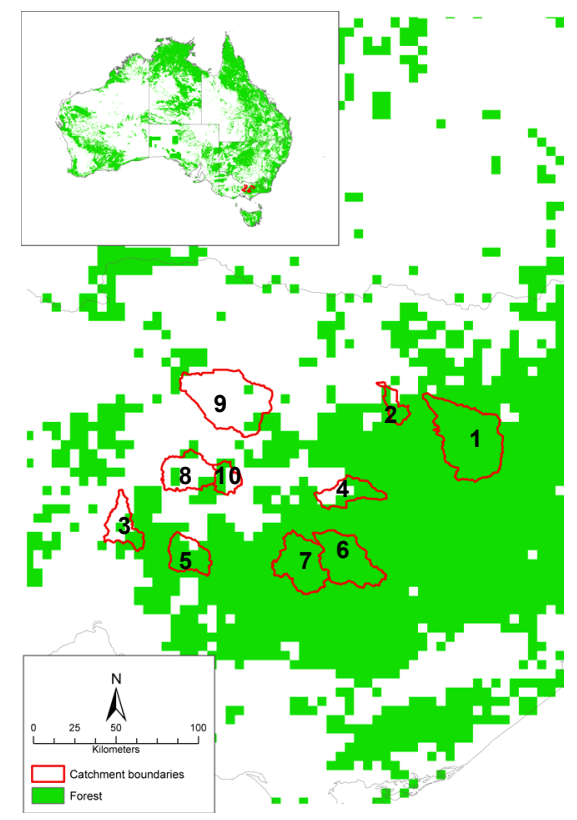

Figure 1. Study area and location of the ten catchments.

The catchment scale land use mapping for Australia which includes 16 land cover types was used to identify forest and non-forest grid cells in a catchment (Figure 1). The 16 land cover type data were produced by the Bureau of Rural Sciences in April 2009 at a $50 \mathrm{~m}$ spatial resolution. The fine resolution dataset provides accurate estimates for land cover types for catchments with an area greater than $50 \mathrm{~km}^{2}$.

\section{METHOD}

\subsection{Rainfall-runoff models}

Two conceptual daily rainfall-runoff models: Sacramento (Burnash et al. 1973) and SIMHYD (Chiew et al. 2002) are used in this study. The model versions used here are very similar to those described in the above references. The models are typical of lumped conceptual rainfall-runoff models, with interconnected storages and algorithms that mimic the hydrological processes used to describe movement of water into and out of storages. Both the models have been widely used in Australia and the USA, including for regionalisation studies to predict runoff in ungauged catchments and for climate impact and land use change studies (Gan and Burges 2006; Zhang and Chiew 2008, Vaze et al. 2011b).

\subsection{Calibration and regionalisation strategies}

In model calibration, three separate sets of calibration experiments are undertaken:

- Experiment 1: Calibrate all the catchments individually for each of the 10 catchments (one parameter set for each catchment: a total of 10 sets of calibrated parameter values);

- Experiment 2: Calibrate all the 10 catchments together using forest and non-forest land cover labels for individual grid cells within each catchment (one calibrated parameter set for all forest grid cells and another for all non-forest grid cells in all the 10 catchment a total of two sets of calibrated parameter values);

- Experiment 3: Drop one catchment out in turn and calibrate the remaining nine catchments together using forest and non-forest land cover labels for individual grid cells within each catchment (one calibrated parameter set for all forest grid cells and another for all non-forest grid cells in all nine catchments, total two sets of calibrated parameter sets).

In the model calibration, the model parameters are optimised to maximise the NSE-bias objective function which is a weighted combination of daily Nash-Sutcliffe (Nash and Sutcliffe 1970) efficiency and a logarithmic function of bias and is given by

$\mathrm{OBJ}=\mathrm{NSE}-5|\ln (1+\mathrm{B})|^{2.5}$ 
where NSE is the Nash-Sutcliffe efficiency of daily streamflows and B is the bias (total modelled error divided by observed total streamflow) (Viney et al., 2009). The modelling at $0.05^{\circ}$ grid cells allows a better representation of the spatial patterns and gradients in the rainfall and the spatial variability in the land cover compared to a lumped catchment modelling approach. The daily runoff for each catchment in the model calibration (and regionalisation) is obtained by aggregating the modelled daily runoff for all the $0.05^{\circ}$ grid cells in the catchment. The Shuffled Complex Evolution global optimisation method (Duan et al. 1993) followed by a local optimisation method (Rosenbrock, 1960), with multiple starting parameter sets, are used to calibrate the models.

The calibrated models ability to predict runoff in 'ungauged' catchments is then assessed by:

- Using parameter values from the geographically closest gauged catchment (nearest neighbour regionalisation);

- Using forest and non-forest parameter sets calibrated for the remaining nine catchments (forest and nonforest regionalisation).

\section{RESULTS AND DISCUSSION}

\subsection{Calibration}

The NSE and bias in model calibration for Sacramento and SIMHYD for individual catchment calibration (Experiment 1) and regional calibration with forest and non-forest parameter sets (Experiment 2) for the 10 catchments is shown in Figure 2. The calibration NSE values for the 10 catchments in Experiment 1 for Sacramento vary between 0.58 and 0.94 with a median value of 0.85 (solid blue squares in Figure 2a). The SIMHYD individual catchment calibration NSE values are slightly lower than Sacramento and vary between 0.46 and 0.90 with a median value of 0.80 (solid red squares in Figure 2a). In Experiment 1, both the models have very small calibration bias with the calibration bias varying between -0.03 and 0.01 for Sacramento and between -0.05 and 0.04 for SIMHYD (solid blue and red squares in Figure $2 b$ ). The calibration NSE values in Experiment 2 for Sacramento vary between 0.43 and 0.90 with a median value of 0.78 (hollow blue squares in Figure 2a) and the SIMHYD calibration NSE values are again slightly lower than Sacramento and vary between 0.43 and 0.85 with a median value of 0.74 (hollow red squares in Figure 2a). In Experiment 2, both the models have larger calibration biases as compared to Experiment 1 with the calibration bias varying between -0.22 and 0.23 for Sacramento and between -0.22 and 0.24 for SIMHYD (hollow blue and red squares in Figure 2b).
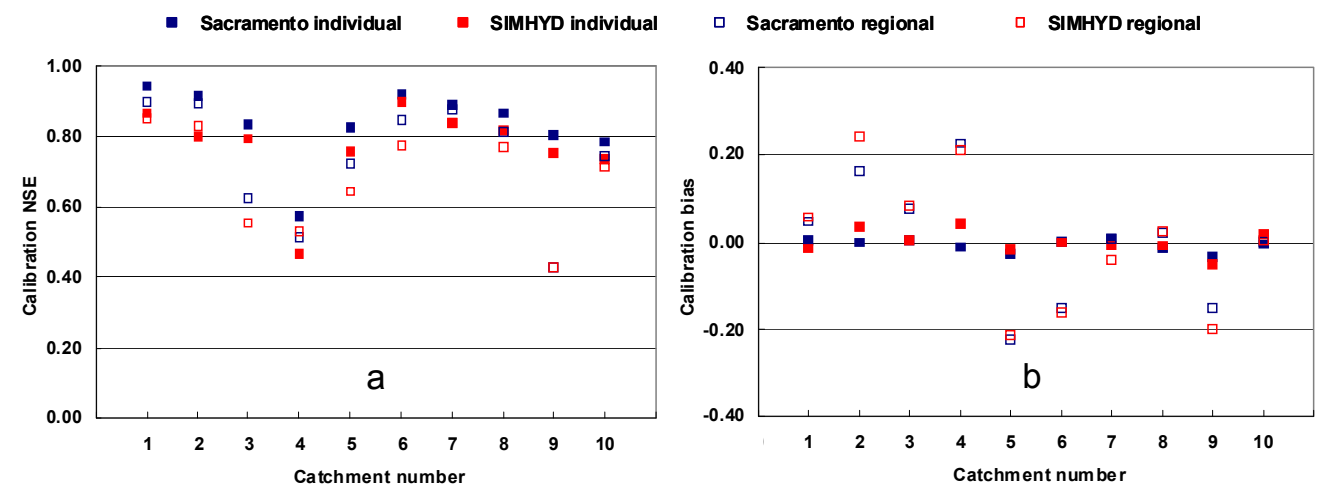

Figure 2. Calibration NSE and bias for Sacramento and SIMHYD models for individual and regional (forest and non-forest) calibrations for the 10 catchments.

The calibration NSE values in Experiment 2 are lower than the NSE values in Experiment 1 for 8 of the 10 catchments for SIMHYD and all the 10 catchments for Sacramento (a reduction of 0.07 and 0.06 in the median NSE for Sacramento and SIMHYD respectively). This is because, in Experiment 1, each catchment is calibrated individually and so there are in total 10 calibrated parameters (one set for each catchment, total of 10 parameter sets), whereas in Experiment 2, all the catchments are calibrated together with only two sets of parameters (one set for forest land cover grids and another for non-forest land cover grids, total of two parameter sets). The relatively small reduction in calibration NSE values in Experiment 2 compared to Experiment 1 (although only calibrating 2 parameter sets instead of 10 sets) may suggest that the calibrations in Experiment 2 are able to incorporate the spatial variability of land cover in the catchments in the calibrated parameter values. Another set of experiments were carried out to verify this where forest and non-forest 
labels were randomly assigned to each of the grid cells within the 10 catchments and the models were calibrated using two sets of parameters (forest and non-forest, two sets of calibrated parameter sets for the 10 catchments). These results show a much larger reduction in calibration NSE values compared to Experiment 2 (a reduction of 0.19 and 0.18 in the median NSE values for Sacramento and SIMHYD respectively). The results from this calibration with random forest and non-forest grid cell confirms that the regional calibrations in Experiment 2 which incorporate spatial land cover information are able to incorporate the land cover signal in model calibration.

The model parameters in Experiment 2 are calibrated by incorporating spatial land cover information in the calibration process using data for all the 10 gauged catchments together. This has the potential to provide regional parameter sets for forest and non-forest land cover types (rather than catchment specific) which may provide better estimates of runoff in ungauged catchments. This is tested using a cross-verification (Vaze and Chiew, 2003) approach in Experiment 3 where one catchment is left out in turn and the remaining 9 catchments are calibrated together using forest and non-forest land cover labels for individual grid cells within each catchment (one calibrated parameter set for all forest grid cells and another for all non-forest grid cells in all the nine catchment, total two sets of calibrated parameter sets). The calibrated forest and nonforest parameter sets are used to simulate runoff for the catchment that was left out and the runoff is compared to the observed runoff for this catchment to determine the ability of the calibrated parameter sets to estimate runoff in ungauged catchments. These results are compared to the commonly used method where calibrated parameters from the geographically closest gauged catchment are used to simulate runoff for the ungauged catchments (nearest neighbour regionalisation method).

The NSE and bias in regionalisation for Sacramento and SIMHYD for individual catchment calibration (using parameters from nearest catchment calibrated in Experiment 1) and regional calibration with forest and non-forest parameter sets ( 2 sets of forest and non-forest parameters in Experiment 3 ) for the 10 catchments is shown in Figure 3. The regionalisation NSE values for the 10 catchments when using calibrated parameters from the geographically closest calibration catchment (from Experiment 1) vary between 0.10 and 0.82 with a median value of 0.58 for Sacramento (solid blue squares in Figure $3 \mathrm{a}$ ) and between -0.09 and 0.79 with a median value of 0.55 for SIMHYD (solid red squares in Figure $3 a$ ). The regionalisation NSE values when using calibrated parameter sets for forest and non-forest land cover grids from Experiment 3 vary between 0.37 and 0.87 with a median value of 0.70 for Sacramento (hollow blue squares in Figure 3a) and between 0.35 and 0.84 with a median value of 0.67 for SIMHYD (hollow red squares in Figure 3a). In model regionalisation, both the models have a relatively larger bias for both the regionalisation methods as compared to bias in model calibration but the simulated runoff is always within
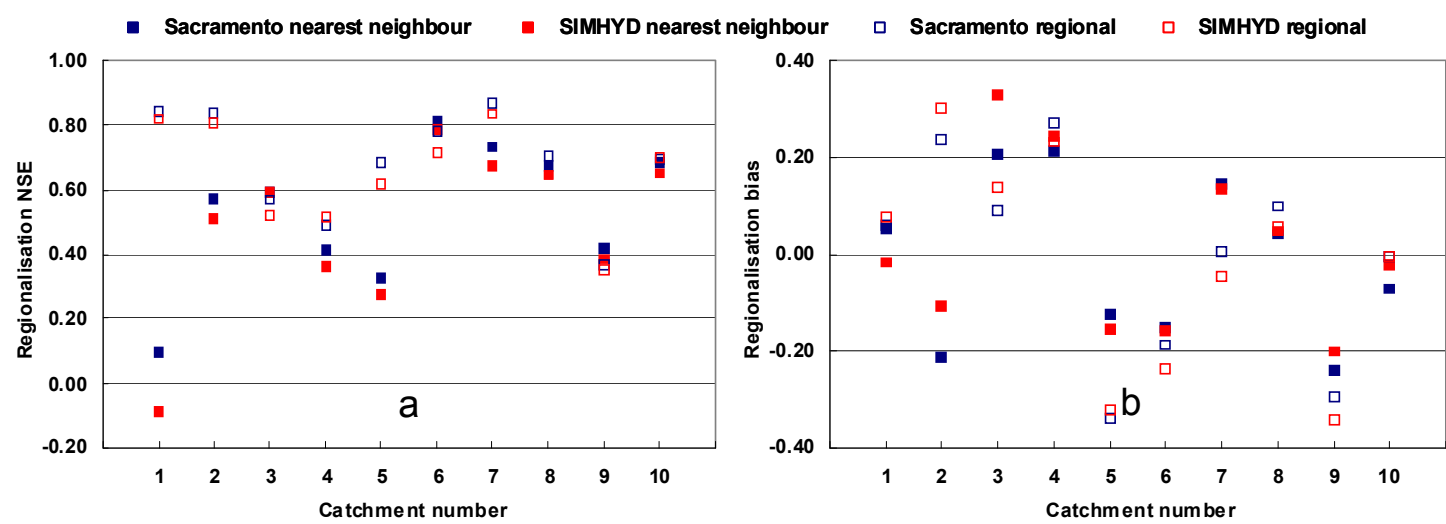

Figure 3. Regionalisation NSE and bias for Sacramento and SIMHYD models for individual and regional (forest and non-forest) simulations for the 10 catchments.

$40 \%$ of the observed runoff (hollow blue and red squares in Figure $3 \mathrm{~b}$ ).

The results show that the regionalisation NSE values when using the regionally calibrated forest and nonforest parameter sets are generally higher than the nearest neighbour regionalisation method. There is an improvement in regionalisation NSE for 7 of the 10 catchment for both the models when using the forest and non-forest parameter sets instead of calibrated parameter values from the geographically closest catchment and this improvement varies between 0.01 and 0.75 for Sacramento and 0.01 and 0.82 for SIMHYD. The bigger improvements are for catchments 1, 2 and 5 where the difference in forest cover between the target and donor catchment is large $(36 \%, 36 \%$ and $32 \%$ respectively). There is a small reduction in regionalisation NSE for 3 of the 10 catchment for both the models when using the forest and non-forest parameter sets 
instead of calibrated parameter values from the geographically closest catchment and this reduction varies between 0.03 and 0.05 for Sacramento and 0.03 and 0.07 for SIMHYD. The median regionalisation NSE when using regionally calibrated parameter sets is 0.12 higher than the median NSE for the nearest neighbour method for both the models.

When comparing the NSE values in model calibration and regionalisation, there is a reduction of 0.17 and 0.25 in the median NSE values for Sacramento and SIMHYD respectively in the individual catchment calibration in Experiment 1 and nearest neighbour regionalisation. There is a much smaller reduction in median NSE of 0.08 and 0.07 for Sacramento and SIMHYD respectively when comparing regional calibration in Experiment 2 and regionalisation using the forest and non-forest parameter sets calibrated in Experiment 3. The smaller reduction in regionalisation NSE values when using forest and non-forest parameter sets reiterate that the regional calibrations which incorporate spatial land cover information are able to incorporate spatial land cover signal in the calibrated parameter values.

The results from this study suggest that incorporating spatial land cover data in model calibration with a gridded model structure provides better estimates of regional model parameter sets for forest and non-forest land cover. The incorporation of spatial land cover information in the regionally calibrated parameters provides improvements in estimates of daily runoff in ungauged catchments over the widely used nearest neighbour regionalisation approach and the regionally calibrated forest and non-forest parameter sets are better suited for predictions in ungauged catchments.

\section{SUMMARY}

This study evaluates the relative benefits of two calibration (local and regional) and regionalisation methods (nearest neighbour and regional forest and non-forest parameters). The modelling experiments are carried out using two rainfall-runoff models (Sacramento and SIMHYD) and daily climate and streamflow data for 10 unregulated gauged catchments from southeast Australia.

Three sets of model calibrations are carried out. In the first set, the rainfall-runoff models are calibrated to individual catchments. In the second set, spatial land cover information is used to calibrate two sets of rainfall-runoff model parameters (one set for forest and another for non-forest). In the third set, a crossverification analysis is carried out where one catchment is dropped out in turn and the models are calibrated for the remaining nine catchments together using forest and non-forest land cover labels for individual grid cells within each catchment. The calibrated models ability to predict runoff in 'ungauged' catchments is then assessed by: (i) using parameter values from the geographically closest gauged catchment (nearest neighbour regionalisation); (ii) using forest and non-forest parameter sets calibrated for the remaining nine catchments (forest and non-forest regionalisation).

The calibration results show that the median of Nash-Sutcliffe efficiency (NSE) for the 10 catchments for individual catchment calibration is slightly higher than that for the regional forest and non-forest calibration. This is to be expected as we are calibrating only two sets of parameter values in the latter case instead of 10 sets. But the regionalisation results show that incorporating spatial land cover information in the gridded calibration of RR model improves runoff prediction in ungauged catchments with the median of regionalisation NSE for the forest and non-forest regionalisation significantly higher than that for the nearest neighbour method.

The results and conclusions here are based on analysis undertaken using only 10 catchments and all these catchments are in close proximity with similar climate and physical characteristics. The results may be different when using catchments spread across a larger region. But the results here suggest that this approach can provide better estimates of runoff within a river basin and it has the potential to be used to estimate the impacts of land cover change. We are currently exploring the applicability and suitability of the approach over a larger region using data from 100 catchments in southeast Australia.

\section{ACKNOWLEDGMENTS}

The work is undertaken within the eWater Catchment Water Yield Estimation Tool (CWYET) project. This work was carried out in the CSIRO Water for Healthy Country Flagship.

\section{REFERENCES}

Bardossy, A. (2007). Calibration of hydrological model parameters for ungauged catchments, Hydrology and Earth System Sciences, 11, 703-710. 
Vaze et al., Assessing different calibration and regionalisation techniques for predictions in ungauged basins

Beven, K., and Freer, J. (2001), Equifinality, data assimilation, and uncertainty estimation in mechanistic modelling of complex environmental systems using the GLUE methodology, Journal of Hydrology, 249, 11-29.

Bloschl, G., and Sivapalan, M. (1995). Scale Issues in Hydrological Modeling - a Review, Hydrological Processes, 9, 251-290.

Burnash, R. J. C., Ferral, R. L. and McGuire, R. A. (1973). A Generalised Streamflow Simulation System Conceptual Modelling for Digital Computers. Joint Federal and State River Forecast Center, Sacramento, Technical Report, 204 pp.

Chiew, F. H. S., Peel, M. C. and Western, A. W. (2002). Application and testing of the simple rainfall-runoff model SIMHYD. In: Singh, V. P. and Frevert, D. K., (eds.), Mathematical Models of Small Watershed Hydrology and Applications. Water Resources Publications, Littleton, USA, pp. 335-367.

Duan, Q. Y., Gupta, V. K. and Sorooshian, S. (1993). Shuffled complex evolution approach for effective and efficient global minimization. J. Optimiz. Theory Appl. 76(3), 501-521.

Elfert, S., Bormann, H., 2010. Simulated impact of past and possible future land use changes on the hydrological response of the Northern German lowland 'Hunte' catchment. Journal of Hydrology 383 (34), 245-255.

Jeffrey, S. J., Carter, J. O., Moodie, K. B. and Beswick, A. R. (2001). Using spatial interpolation to construct a comprehensive archive of Australian climate. Environmental Modelling and Software, 16, 309-330.

Merz, R., and Bloschl, G. (2004). Regionalisation of catchment model parameters, Journal of Hydrology, 287, 95-123.

Nandakumar, N., and Mein, R.G. (1997). Uncertainty in rainfall-runoff model simulations and the implications for predicting the hydrologic effects of land-use change. Journal of Hydrology 192 (1-4), 211-232.

Nash, J.E., Sutcliffe, J.V., (1970). River flow forecasting through conceptual models part I - A discussion of principles. Journal of Hydrology 10 (3), 282-290.

Oudin, L., Andréassian, V. C., Perrin, C., Michel, C. and Le Moine, N. (2008). Spatial proximity, physical similarity, regression and ungaged catchments: A comparison of regionalization approaches based on 913 French catchments, Water Resour. Res., 44, W03413, doi:03410.01029/02007WR006240.

Parajka, J., Merz, R. and Bloschl, G. (2005). A comparison of regionalisation methods for catchment model parameters, Hydrology and Earth System Sciences, 9, 157-171.

Rosenbrock, H. H. (1960). An automatic method for finding the greatest or least value of a function, Computer Journal, 3, 175-184.

Sivapalan, M., Takeuchi, K., Franks, S. W., Gupta, V. K., Karambiri, H., Lakshmi, V., Liang, X., McDonnell, J. J., Mendiondo, E. M., O'Connell, P. E., Oki, T., Pomeroy, J. W., Schertzer, D., Uhlenbrook, S. and Zehe, E. (2003). IAHS decade on Predictions in Ungauged Basins (PUB), 2003-2012: Shaping an exciting future for the hydrological sciences, Hydrological Sciences Journal-Journal Des Sciences Hydrologiques, 48, 857-880.

Tuteja N. K., Vaze, J., Teng, J. and Mutendeudzi, M. (2007). Partitioning the effects of pine plantations and climate variability on runoff from a large catchment in southeastern Australia, Water Resources Research, 43, W08415, doi:10.1029/2006WR005016.

Vaze, J. and Chiew, F.H.S. (2003). Comparative evaluation of urban stormwater quality models. Water Resources Research, Vol. 39, NO. 10, 1280.

Vaze, J., Barnett, P., Beale, G.T.H., Dawes, W., Evans, R., Tuteja, N.K., Murphy, B., Geeves, G., and Miller, M. (2004). Modelling the effects of landuse change on water and salt delivery from a catchment affected by dryland salinity in south-east Australia, Hydrological Processes, Vol. 18, pp. 1613 - 1637.

Vaze, J. and Teng, J. (2011). Future climate and runoff projections across New South Wales, Australia results and practical applications, Hydrol. Process. 25, 18-35, doi: 10.1002/hyp.7812.

Vaze, J., Chiew, F. H. S., Perraud, JM., Viney, N., Post, D. A., Teng, J., Wang, B., Lerat, J., Goswami, M., (2011a). Rainfall-runoff modelling across southeast Australia: datasets, models and results. Australian Journal of Water Resources, Vol 14, No 2, pp. 101-116.

Vaze, J., Davidson, A., Teng, J. and Podger, G. (2011b). Impact of climate change on water availability in the Macquarie-Castlereagh river basin in Australia. Hydrological Processes, DOI: 10.1002/hyp.8030.

Vertessy, R. A. (1999). The impacts of forestry on streamflows: A review, in Proceedings of the Second Forest Erosion Workshop, May 1999, Tech. Rep. 99/6, CRC for Catchment Hydrol., Melbourne, Australia.

Viney, N. R., Perraud, J-M., Vaze, J., Chiew, F.H.S., Post, D.A. and Yang A. (2009). The usefulness of bias constraints in model calibration for regionalisation to ungauged catchments. 18th World IMACS / MODSIM Congress, Cairns, Australia 13-17 July 2009. http://mssanz.org.au/modsim09. 
Vaze et al., Assessing different calibration and regionalisation techniques for predictions in ungauged basins

Young, A. R. (2006), Stream flow simulation within UK ungauged catchments using a daily rainfall-runoff model, Journal of Hydrology, 320, 155-172.

Zhang, Y. Q. and Chiew, F. H. S. (2008). Can remote sensing data improve short-term rainfall-runoff simulation?, paper presented at Water Down Under 2008, April 2008, Adelaide: Engineers Australia. 